\title{
Ewolucja greckich środków społecznego przekazu, z uwzględnieniem komunikatu reklamowego
}

Grecja to państwo leżące w południowo-wschodniej Europie. Pod
względem wielkości zajmuje 14 miejsce na kontynencie. W odniesie-
niu do ewolucji i rozwoju środków społecznego przekazu, ważnym fak-
tem jest, że aż $80 \%$ powierzchni kraju zajmują góry. Duży wpływ na
rozwój wszelkich form komunikacji masowej, wywarła w Grecji również
jej historia. W IX w. p.n.e. powstał tam system państw miast (polis), wśród
których znajdowały się również Ateny, które stały się później kolebką de-
mokracji, oznaczającej rządy ludu. Łącznikiem pomiędzy różnymi polis
był wówczas ten sam język oraz religia. Grecy broniąc się przed Persami
zakładali związki, które wyłaniały wspólną władzę. IV w. p.n.e. to okres
hellenistyczny, w którym władzę sprawował Filip II i Aleksander Wielki.
Po tym okresie w II w. p.n.e. ziemie greckie opanował republikański
Rzym, aż do V w. n.e., kiedy to Grecja dostała się pod panowanie Cesar-
stwa Bizantyjskiego. Po upadku Bizancjum, kontrolę nad Grecją na cztery
wieki przejęła Turcja. Okres ten charakteryzuje się tworzeniem przez
kupców greckich, organizacji niepodległościowych, zwanych heteriami.
Po tej okupacji, w roku 1830 Grecja na rok staje się republika, ale już
w roku 1831 władcą państwa zostaje Otton I, a ustrój przybiera formę mo-
narchii, która cały czas walczy o odzyskanie swoich ziem i zjednoczenie
całego narodu greckiego. Ustrój monarchistyczny trwał w Grecji aż do
roku 1973, a wiec prawie do końca dyktatury czarnych pułkowników
(1967-1974), kiedy to proklamowano republikę. Okres ten charakteryzu-
je się licznymi bojkotami telewizji państwowej.
Rozważania na temat greckich mediów (radio, telewizja, prasa)
i związanych z nimi komunikatów reklamowych rozpocząc należy o kine-
matografii. Od niej właśnie rozpoczęła się w Grecji publiczna transmisja
różnych przekazów wizualnych i audiowizualnych. Pierwsze publiczne
wyświetlanie filmów rozpoczęło się w roku 1897, a więc o wiele wcześ-
niej niż powstała tam telewizja, a reakcje widowni były czasami zaska-
kujące (np. rzucanie kamieniami w ekran). Kinematografia rozwijała się 
bardzo powoli. Pierwsze Greckie filmy oparte były na mitologii. Produkcja filmowa, z uwagi na brak reklam nie przynosiła wysokich dochodów i była na niskim poziomie. W latach siedemdziesiątych XX w. powstaje Nowe Kino Greckie (NEK), a filmy dotyczyć zaczynają spraw społecznych. W tym samym okresie zaczyna pojawiać się telewizja, która odciagga widownię od kina ${ }^{1}$. Kinematografia dla ratowania swojej pozycji zaczyna po raz pierwszy, w roku 1982 wykorzystywać promocję, zarówno w kraju, jak i za granicą. W dużej mierze przyczyniła się do tego minister kultury, znana aktorka Melina Mercouri.

Po drugiej wojnie światowej w Grecji istniały tylko państwowe stacje nadawcze, radiowe i telewizyjne. Okres od 1967 do 1974 to okres panowania czarnych pułkowników, którzy tłumili działalność poszczególnych stacji, zamykając je, cenzurując i ograniczając prawa człowieka do informacji. Reżim wojskowy wykorzystywał środki społecznego przekazu dla własnych interesów ideologicznych i politycznych. Pewna deregulacja tego monopolu nastapiła dopiero w roku 1989. Okres ten charakteryzuje się również powstawaniem prywatnych stacji nadawczych, które nie uzyskawszy koncesji na pasmo nadawania, prowadziły swoją działalność niezupełnie legalnie ${ }^{2}$. Nie oznaczało to jednak zakończenia wpływu partii politycznych, na działalność poszczególnych środków społecznego przeka$\mathrm{zu}$, a regulacje dotyczące prasy nawiązywały do rządów Ioannisa Metaxasa z roku 1930. Przez większość historii, każda partia grecka posiadała własną gazetę. Po 1974 r. media greckie zostały przekształcone. Zaczęto na szeroką skalę zamieszczać reklamę, w celu zwiększenia przychodów. Jednak prawdziwy rozwój nastąpił w roku 1980, kiedy to liczba stacji telewizyjnych i radiowych zaczęła wzrastać. Wtedy nastąpiła prawdziwa inwazja reklam, nie tylko rodzimych, ale również tych, ściąganych z zagranicy. Komunikaty reklamowe na dużą skalę, zaczęły pojawiać się również w gazetach. Przodującą w greckiej prasie była reklama papierosów, instytucji edukacyjnych, podróży i źródeł dochodu. Od momentu przyjęcia do UE, Grecja jest jednak zobowiązana do przestrzegania prawa unijnego, dotyczącego tych środków i związanej z nimi emisji reklam. Ta deregulacja spoza kraju, stała się najważniejszym ustawodawstwem, dotyczącym środków społecznego przekazu. Pojawienie się w Grecji wolności słowa dla wszystkich obywateli, przyczyniło się do rozwoju prywatnego

1 A. M. Brzeziński, Grecja, Warszawa 2002, s. 53, 105, 157-159, 181, 200-201.

2 S. Papathanassopoulos, Broadcasting, Polityka i państwo w socjalistycznej Grecji, „Media, Kultura, Społeczeństwo” 1990, nr 12, s. 387-397. 
sektora nadawczego, który zaczął uruchamiać własne stacje telewizyjne, np. Mega Chanel. W efekcie, w całej Grecji powstało bardzo dużo nadajników, których liczba nie do końca była znana, a większość z nich, jak już wspomniano działała nielegalnie ${ }^{3}$. Można przypuszczać, że taka sytuacja doprowadziła do dominacji prywatnych magnatów medialnych, a upadku nadawcy państwowego, przyczyniając się również do braku nadzoru.

Grecki parlament zalegalizował prywatne stacje radiowe i telewizyjne dopiero w 1989 roku. W następnych latach, media szczególnie te prywatne, zaczęły krytykować rząd, zmuszając do poprawy wizerunku państwa.

Uznaje się, że greckie radio zaczęło nadawanie w roku 1939, za czasów rządów Ioannisa Mataxasa. Telewizja swoją działalność rozpoczęła dopiero w roku 1960 za czasów dyktatury czarnych pułkowników ${ }^{4}$. Grecki system medialny stał się wówczas monopolem państwa. Radio i telewizja sympatyzowały i powiązane były z rządem. Cała polityka decyzji programowych, układana była i zależała od rządu. Taka sytuacja przypominająca paternalizm, była jedną z ważniejszych funkcji rządu. Zarówno konserwatyści w latach 1974 do 1981, jak i socjaliści w latach 1981 do 1989, nie zezwalali na autonomię nadawcom.

Istniejące dzisiaj państwowe, greckie media są spadkobiercami przyzwyczajeń aparatu państwowego, opierając się na moralnej i politycznej korupcji. Likwidacja tego nagannego systemu medialnego wymaga jednak sporo czasu i wysiłku. Grecka społeczność jest kształtowana przez intelektualne i emocjonalne modele życia, narzucane przez tamtejsze media. Dzisiejsze publiczne media są kanałem służącym do przenoszenia spraw społecznych, politycznych i różnego rodzaju demagogii, jako produktu do spożycia. Skutkiem takiej polityki medialnej jest fakt, że greckie dziennikarstwo ewaluowało pomiędzy oddziaływaniem magnatów medialnych a politycznymi ośrodkami władzy, o zjednanie sobie audytorium, zamiast skupić się na samym przekazie. Dzisiejsze greckie media opierają się przede wszystkim na zdobyciu jak największych zysków, czerpiąc wzorce z lepiej rozwiniętych odpowiedników zachodnich. Zdobywanie tych zysków wiąże się oczywiście z zamieszczaniem różnych reklam, przeznaczonych dla odpowiednich odbiorców i zdobywaniem reklamodawców za wszelką cenę. Najwięcej środków finansowych prze-

3 „European Journal of Communication”, New Delhi 1997, vol. 12, s. 351-368.

4 http://www.pressreference.com/forum/\&rurl, 12 października 2010. 
znacza się na reklamy telewizyjne i w prasie, która zmuszona została do podniesienia swoich standardów w postaci koloru, składu i samej zawartości. Takie zwrócenie uwagi na potencjalnego konsumenta, rozpoczęło się dopiero w roku 1990, kiedy zaczęto szukać odbiorców spoza sceny politycznej, dzieląc konsumenta na różne typy preferencji. Wydaje się, że to telewizja jest największym przekaźnikiem ofert skierowanych do konsumentów, które zastąpiły ogłoszenia i propagandę systemu politycznego. Nie oznacza to jednak, że wyrwane z politycznego systemu media, zaspakajają potrzeby swoich odbiorców w sposób uczciwy, sprawiedliwy i skuteczny ${ }^{5}$. Widzowie często narzekają, że zbyt wiele czasu poświęca się na emisję reklam, zamiast nadawać programy informacyjne i kulturowe.

Telewizja prywatna posiada dominującą pozycję pod względem przychodu z reklam (np. ANT 1 i Mega). Warto zaznaczyć, że telewizja kablowa w tym kraju jest bardzo słabo rozwinięta, ze względu na górzyste położenie i zainteresowanie mieszkańców. W odniesieniu do radia, większość stacji nadawczych jest prywatna i działa bez zezwolenia. Telewizja cyfrowa, regulowana przez ustawę 2644/1998 posiada swoje dwa podmioty: publiczny - ERT i prywatny NOVA ${ }^{6}$. Nadawcy prywatni cieszą się w Grecji największą popularnością, zdobywając widzów dzięki rozrywce, filmom fabularnym i teleturniejom, posiadając przy tym duży dystans do polityki. Takie ramy programowe wpływają również na większe zainteresowanie reklamodawców, którzy chętniej korzystają z prywatnej oferty.

Główne postanowienia dotyczące działalności środków społecznego przekazu w Grecji i związanych z nimi praw, należących się społeczeństwu, zawarte zostały w Konstytucji greckiej. Zgodnie z ustawą zasadniczą i jej art. 2, najważniejszym obowiązkiem państwa jest szacunek dla człowieka i ochrona jego wartości. Jednak najważniejszymi postanowieniami związanymi ze środkami tego rodzaju jest zapis art. 5A stanowiący, że każdy ma prawo do informacji i przynależności do społeczeństwa informacyjnego, z zastrzeżeniem, że ograniczenie tego prawa może zostać wprowadzone tylko i wyłącznie ze względu na bezpieczeństwo państwa, przestępczość, ochronę praw i interesów osób trzecich. Art. 9A odnosi się natomiast do ochrony danych stanowiąc, że każdy ma prawo do takiej ochrony, zwłaszcza przy wykorzystywaniu danych za pomocą środków elektronicznych. Kolejne postanowienie zawarte zostało w art. 14. Zgod-

${ }^{5}$ Zob. „Emphasis. A Journal of Hellenic Issues” 1995, vol. 1, Issue 1.

${ }^{6}$ Europejskie Centrum Dziennikarstwa, http://www.info.at.ejc.net, 9 października 2010 r. 
nie z jego wytycznymi, każdy może wyrażać swoje poglądy w mowie, piśmie i w prasie, której zapewnia się wolność i zakaz cenzury. W pkt 3 tego artykułu zapisano, że konfiskata gazet i innych druków, zarówno przed jak po ich rozpowszechnianiu jest m.in. możliwa tylko wtedy, gdy zawiera nieprzyzwoite treści, narusza normy obyczajowe oraz w przypadkach określonych w ustawie. Warto również zaznaczyć, że przestępstwa popełnione przez prasę, zgodnie z art. 97 pkt 3 rozpatrywane są przez powszechne sądy karne, na zasadach dotyczących kompetencji tych sadów. Art. 116 ust. 2 odnosi się bezpośrednio do dyskryminacji stanowiąc, że zastosowanie dyskryminacji pozytywnej w celu promowania równości kobiet i mężczyzn nie jest dyskryminacją w sensie kulturowym. Takim postanowieniem, państwo chce znieść kulturowo przestarzałą wizję greckiej kobiety. Prawa i wolności obywatelskie obowiązujące w państwie greckim, podlegają specjalnej ochronie, polegającej na zakazie wprowadzania jakichkolwiek zmian w zapisach konstytucyjnych (art. 110). Pewne wątpliwości i zastrzeżenia można mieć w stosunku do art. 101 Działu F Konstytucji, w którym deklaracja wyjaśniająca stanowi, że zarówno administracja, jak i ustawodawca w swojej działalności normatywnej, powinni brać pod uwagę szczególne warunki przynależących do Grecji wysp $^{7}$. W przypadku greckiej rzeczywistości i faktów stwierdzonych na obszarach wyspiarskich, wydaje się, że prawo greckie nie wywiązuje się ze swoich konstytucyjnych i unijnych obowiązków lub dzieli ustawodawstwo na dwie kategorie: lądową i wyspiarską, posiadającą wąski zakres i wiele przywilejów. Taki stan rzeczy odnieść można również do art. 106 Działu A, mówiącego o promowaniu rozwoju regionalnego m.in. wysp, co godziłoby mocno w ustawodawstwo unijne.

Greckie środki społecznego przekazu są nadzorowane przez NCRTV - Krajową Radę Radiofonii i Telewizji, która jest organem niezależnym, a jej działania podlegają kontroli sądów. Rzeczą interesującą jest fakt, że posiada ona uprawnienia do nakładania kar za naruszenie kodeksów etycznych. Taka państwowa kontrola, ma na celu zapewnienie obiektywności rozpowszechniania informacji, dzieł literackich i sztuki, zagwarantowania odpowiedniego poziomu audycji, zgodnie ze społeczną misją radiofonii i telewizji oraz zachowania szacunku oraz ochrony dzieci i młodzieży ${ }^{8}$. Dopiero w roku 1994 utworzone zostało Ministerstwo ds.

7 Zob. Konstytucja Grecji, Warszawa 2005.

8 Art. 15, ibidem, s. 45. 
Prasy i Mediów. Nad przestrzeganiem etyki dziennikarskiej oraz praktyk reklamowych czuwa NBC (National Broadcast Corporation). Rola i znaczenie organów regulacyjno-kontrolnych jest jednak bardzo dyskusyjne w porównaniu do greckiej rzeczywistości.

Do najważniejszych kodeksów deontologicznych, odnoszących się do środków społecznego przekazu i dyskursów reklamowych, należy Grecki Kodeks Reklamy. Postanowiono w nim, że odpowiedzialność za reklamę ponoszą wszyscy, którzy związani są z jej emisją i produkcją. Stwierdzono również, że wszystkie reklamy powinny być przyzwoite (art. 1), nie powinny wykorzystywać zaufania konsumenta lub braku doświadczenia i wiedzy (art. 2), nie opierać się na strachu i przesądach, przemocy, świętych tekstach, kulturowym i duchowym dziedzictwie, dyskryminacji oraz na przekonaniach religijnych. Reklamy nie powinny wprowadzać w błąd, poprzez cechy produktu, wartości produktu, warunki płatności, dostawy, wymiany, zwrotu, naprawy i konserwacji oraz warunki gwarancji (art. 4). Komunikaty porównawcze powinny być zgodne z zasadami uczciwej konkurencji, a elementy porównywane powinny być oparte na faktach, możliwych do stwierdzenia (art. 5). W art. 6 stwierdzono, że nie powinny one powoływać się na jakiekolwiek rekomendacje chyba, że związane są one z osobistym doświadczeniem występującej w reklamie osoby. Przekaz reklamowy nie powinien również oczerniać innej firmy lub jej produktu, bezpośrednio lub pośrednio (art. 7). Zamieszczenie w reklamie wizerunku prywatnej osoby, uzależnione jest od jej zgody (art. 8). W odniesieniu do przedsiębiorstw konkurencyjnych, zakazano nieuzasadnionego użycia nazwy lub znaku innej firmy lub instytucji oraz jej kampanii reklamowej. Zabroniono również naśladownictwa innych reklam, które wprowadzić mogą konsumenta w błąd (art. 10). Osobne wytyczne dotyczą identyfikacji przekazu reklamowego, który powinien być wyraźnie rozpoznawalny (art. 11). Wstępem do uregulowań dotyczących dzieci jest art. 12 powyższego Kodeksu, w którym zabroniono obrazów i opisów niebezpiecznych praktyk i sytuacji, ze szczególnym uwzględnieniem ochrony i bezpieczeństwa dzieci. Art. 13, odnosi się wprost do dzieci i młodzieży. W pkt 1 tego artykułu postanowiono, że reklama nie może wykorzystywać naturalnej ich łatwowierności i braku doświadczenia. Pkt 2 mówi o zakazie umieszczania elementów, które mogą zaszkodzić psychicznie, moralnie i fizycznie. Osobne uregulowania dotyczą komunikatów reklamowych tytoniu i alkoholu, skierowanych do dzieci. W pkt 3d postanowiono, że nie mogą one bezpośrednio namawiać małoletnich do zakupów lub korzystania z usług, wykorzystując ich brak 
doświadczenia i zaufania, do namowy rodziców lub osoby trzeciej do ich zakupu oraz pokazywać małoletnich w trudnej sytuacji. W odniesieniu do napojów alkoholowych w podpunkcie a, b, c, d, e i f postanowiono, że reklama taka nie może być skierowana do małoletnich, nie może dotyczyć atrakcyjności ciała; sugerować, że spożycie alkoholu przyczyni się do sukcesu seksualnego i społecznego, sugerować że napoje te mają właściwości terapeutyczne, że abstynencja jest niemodna oraz, że spożycie alkoholu jest korzystne dla człowieka. Pkt 4 zabrania również reklamowania papierosów, innych wyrobów tytoniowych i lekarstw wydawanych na receptę oraz usług seksualnych ${ }^{9}$.

W art. 16 wymienione zostały komitety I-go i II-go stopnia, które maja czuwać w danym przedsiębiorstwie nad realizacją powyższego Kodeksu. Art. 17 dotyczy moralnego i prawnego obowiązku przestrzegania powyższych regulacji. Zakłada on, że obowiązek ten dotyczy wszystkich elementów reklamy, a za jego zgodność odpowiedzialni są reklamodawcy, agencje reklamowe, wykonawcy, wydawcy lub jakiekolwiek inne strony uczestniczące w produkcji i ekspozycji komunikatu reklamowego.

Kolejnym ważnym dokumentem regulującym grecki przemysł reklamy oraz środki służące emisji przekazów reklamowych jest grecka ustawa z 26 grudnia 1913 roku o zwalczaniu nieuczciwej konkurencji. Zgodnie z postanowieniami art. 6 reklama dotycząca towarów, które nie stanowią własności upadłego przedsiębiorstwa, a reklamowane są jako należące do niego jest zabroniona. Zakazano również przekazów, które odnoszą się do likwidacji danego zakładu chyba, że została taka informacja umieszczona w reklamie, a zgodę na takie działania musi wydać sąd. W art. 13 zabroniono wykorzystywania cudzego nazwiska, nazwy firmy lub oznaczenia przedsiębiorstwa, które prowadzić mogą do pomyłki w jego identyfikacji oraz nałożono obowiązek odszkodowania, jeżeli działanie było zamierzone. Bezpośrednio związanym z tym postanowieniem jest art. 14 nakładający na wprowadzającego w błąd karę pozbawienia wolności na okres nieprzekraczający sześciu miesięcy i grzywny. Równocześnie zaznaczono, że powyższych przepisów ustawy nie stosuje się do ochrony handlowych i przemysłowych znaków towarowych, co do których zastosowanie mają inne przepisy prawne, $\mathrm{z}$ zaznaczeniem, że dotyczy to tylko zna-

9 Grecki Kodeks Reklamy (utworzony przez HAACA i GAA oraz greckie stacje radiowe i telewizyjne), http://www.aeforum.org/reg_enf?greece_2PDF\&rurl, 10 października $2010 \mathrm{r}$. 
czących zmian i tylko wtedy, gdy istnieje duże prawdopodobieństwo wprowadzenia w błąd ${ }^{10}$.

Ważnym i zdumiewającym jest również rozporządzenie Independent Television Commission, Rulet Advertisements to Children 1997, ustanawiające w Grecji zakaz reklamy zabawek dla dzieci od godz. 7 do 22 oraz zakaz reklamy zabawek wojennych ${ }^{11}$. Przepis ten jest jednak martwym przepisem, nierespektowanym przez telewizje prywatne.

Greckie prawo dotyczące środków społecznego przekazu i związanych z nimi komunikatów reklamowych w większości uregulowań podobne jest do ustawodawstwa europejskiego. Prawo to jednak, podobnie jak w innych krajach unijnych nie jest do końca przestrzegane, a samowola reklamodawców widoczna jest w wielu miejscach. Nagminnymi wykroczeniami ze strony przemysłu reklamowego są w Grecji reklamy wielkoformatowe. Na ulicach greckich miast znajdują się tysiące nielegalnych reklam tego typu, które utrudniają przejście pieszym i powodują wypadki samochodowe, mimo ustawowego zakazu. Greckie prawo reklamy zewnętrznej wyraźnie zabrania nielegalnego ustawiania tego typu reklam na poboczach dróg i dachach domów, jeżeli stanowią one zagrożenie dla ruchu pieszego i kołowego. Prawo nie jest jednak do dnia dzisiejszego respektowane, ponieważ taki układ wykorzystywany był kiedyś przez partie polityczne, do reklamowania swoich kandydatów w kampaniach wyborczych. Przyczyną takiej sytuacji, była również grecka korupcja, polegająca na przyjmowaniu przez władze lokalne łapówek za postawienie bilboardów, które popierane były przez różne państwowe i prywatne przedsiębiorstwa. Pewne zmiany nastąpiły dopiero po objęciu władzy przez George Papandreu, który zdecydował się nie korzystać z tego typu promocji. Polityka ta zaczyna się więc powoli zmieniać. Ministerstwo Infrastruktury i Transportu uruchomiło stronę internetową ${ }^{12}$, na której zgłaszać można nielegalne bilboardy, a policja drogowa usuwać zaczęła te, które utrudniają ruch, stanowiąc zagrożenie dla pojazdów samochodowych ${ }^{13}$.

${ }^{10}$ Ustawa 146 z dnia 26 grudnia/stycznia 1913/27th 1914 o zwalczaniu nieuczciwej konkurencji, http://www.aeforum.org/reg_env/greece_2PDF\&RURL, 10 października $2010 \mathrm{r}$.

${ }^{11}$ Dzieci i reklama, PPU.org.uk., http://www.ppu.org.uk/chidren/advertising_toys_eu.html, 11 października $2010 \mathrm{r}$.

${ }_{12}^{12}$ www.illegalsigns.gov.gr.

${ }_{13}$ Mieszkańcy Aten walczq $z$, killer” bilboardami, http://www.translate.googleusercontent.com/translate_c?hl+pl\&langpair, 10 października $2010 \mathrm{r}$. 
Kolejną kontrowersyjną reklamą jest komunikat dotyczący wyrobów tytoniowych. W roku 1992 zakazano tylko reklamy i sponsorowania tych wyrobów w telewizji. W 2005 roku zakaz objął również prasę, radio, Internet $\mathrm{i}$ inne wydawnictwa. Pozostał jednak ustawowy marketing bezpośredni w postaci reklam w kawiarniach, pubach i kafenionach. Następne restrykcje, uchwalone zostały w roku 2008 w ustawie 3730/2008. Zabraniają one dotychczasowej promocji i sprzedaży w szkołach, uczelniach i szpitalach. Kolejna nowelizacja zakazu reklamy wyrobów tytoniowych nastapiła w roku 2009, zakazując wszelkich form reklamy na bilboardach, a dopuszczając ją tylko we wnętrzu sklepów tytoniowych. W tym samym roku wydany został również całkowity zakaz palenia w większości miejsc publicznych $^{14}$. Zmiany dotyczące ustawodawstwa komunikatu reklamowego powinny jednak odbywać się w tym kraju ze szczególnym uwzględnieniem przestrzegania przepisów UE. Ostatnie lata pokazują, że w kwestii zapisów Grecja zaczyna takie posunięcia stosować. Realia rzeczywistości sąjednak zupełnie odmienne. Nadal na terenie Grecji zobaczyć można reklamy wyrobów tytoniowych firm „Karelia” (grecka marka papierosów), „Winston”, „Camel” czy „Davidoff”. Zmiany widoczne są tylko na obiektach Executive Kiosk w Grecji kontynentalnej, gdzie na dachach, zamiast reklamy danej marki papierosów zamieszcza się teraz nazwę sieci zrzeszającej powyższe kioski. Warto zaznaczyć, że reklama wyrobów tytoniowych występuje nadal na Krecie, gdzie każdy kiosk z papierosami i prasą zawiera reklamę firmy tytoniowej, a przed punktami sprzedaży papierosów ustawione są tzw. namioty, reklamujące daną markę i podające cenę. $\mathrm{Na}$ wyspie tej bardzo często spotyka się również reklamy papierosów zamieszczane na przystankach autobusowych i lotniskach oraz plakatach wielkoformatowych. Sytuacja na greckiej wyspie Kreta jest pozostałością po uchylonej dyrektywie 98/43/WE Parlamentu Europejskiego i Rady z 6 lipca 1998, która dopuszczała na terytorium Grecji reklamę wyrobów tytoniowych, w ramach specjalnego systemu przyznawania licencji, z powodów socjalnych (tzw. periptera) - sytuacja ta, budzi jednak wiele wątpliwości, biorąc pod uwagę ochronę zdrowia przed skutkami używania tytoniu oraz stoi w sprzeczności z art. 1 i 3 oraz pkt 3 i 10 preambuły dyrektywy 2003/33/WE Parlamentu Europejskiego i Rady z 26 maja 2003 r. Nie wiadomo jak odnieść taki stan rzeczy do konstytucyjnego zapisu, który

14 A. Syssilas, A\&K Mataxopoulos i Partnerzy, Reklamy wyrobów tytoniowych w Grecji: droga do catkowitego zakazu, http://www.gala-marketlaw.com/joomla4/index.php\%3Foption\%3Dcom-conl, 10 października 2010 r. 
stanowi, że państwo chroni zdrowie obywateli, poprzez specjalne środki służące tej ochronie i udzielanie pomocy ${ }^{15}$.

W dużych miastach reklamy z elementami damskiego sex appealu widoczne są na reklamach wielkoformatowych promujących np. kosmetyki firmy „DIOR”. Na prywatnym kanale telewizyjnym MEGA, emitowana jest również reklama, nie do końca prawnie wyjaśniona e-papierosów, powiązana z telesprzedażą, co rzadko spotykane jest w zachodniej Europie (www.mondoshop.tv). Na tym samym kanale reklamuje się również, z wykorzystaniem piękna i erotyki kobiecego ciała Internet firmy „Vodafone". Takie podejście, nie do końca zgodne z prawem, wydaje się uzasadnione ze względu na słaby rozwój Internetu w Grecji. Nie do końca zasadne jest jednak reklamowanie na powyższym kanale, środków do zwalczania owadów „Fly Ender” przez skąpo odziane kobiety i kontakty damsko-męskie. Państwowa telewizja ERT Word, która jest kanałem skierowanym do emigrantów, podczas przerw w programach nadaje reklamy o kulturze, krajobrazie i zabytkach Grecji. Bardzo drastyczne reklamy typu społecznego, znaleźć można na kanale SKAI. Przedstawiają one np. śmiertelne sceny z wypadków samochodowych, aby uczulić ludzi na jazdę $\mathrm{w}$ zapiętych pasach bezpieczeństwa ${ }^{16}$.

Przypuszczać należy, że wielu reklamodawców widzi w regulacjach rządowych i kodeksowych ingerencję w ich wolność słowa, a językowe zróżnicowania, dotyczące unormowań unijnych, wykorzystywane sąjako elementy zmniejszające oddziaływanie europejskiego ustawodawstwa. Podstawy ochrony wolności reklamy i środków społecznego przekazu, związane z wolnością słowa znajdują się w greckiej Konstytucji. Nie wiadomo jednak jak odnieść grecką rzeczywistość do zapisów konstytucyjnych, które stanowią również, że uznane normy i umowy prawa międzynarodowego, które zostały ratyfikowane w drodze ustawy, stanowią integralną część prawa greckiego i posiadają wyższą moc, niż sprzeczne $\mathrm{z}$ nimi postanowienia greckiej ustawy zasadniczej ${ }^{17}$. Można przypuszczać, że panujące w Grecji bezprawie, dotyczące reklamy i środków jej przekazu, na podstawie art. 77 Konstytucji, wynika wprost z winy

15 Art. 21, Konstytucja, op. cit., s. 51.

16 Wszystkie dane i przykłady dotyczące komunikatów reklamowych występujących na terenie Grecji, pochodzą z badań i obserwacji autora, przeprowadzonych na terenie tego kraju w latach 2008-2010.

17 Art. 28, Konstytucja, op. cit., s. 55. 
władzy ustawodawczej, która dokonywać powinna autentycznej wykładni ustaw $^{18}$.

Duży wpływ reklamy na społeczeństwo greckie, spowodował malejącą atrakcyjność na rodzime produkty, co doprowadzić musi do ograniczenia importu niektórych towarów, w celu nie załamania się produkcji rodzimej. Wbrew utrwalonemu przekonaniu, że greckie społeczeństwo jest wrogie temu, co obce kulturowo i trudno przyswaja obce wzorce kulturowe, społeczność grecka bardzo szybko korzystać zaczęła z napływających z państw zachodniej Europy, reklam różnych produktów i usług.

\section{Summary}

In terms of the means of social communication, Greece is a unique country. Its media system has been significantly influenced by the culture and history of political and social relations. Radio and press emerged at a time of warfare and the struggle for independence, whereas television began and developed in the period of political conflict in the $20^{\text {th }}$ century, which is still evident in Greek public television. Regulations concerning the media are not fully observed there. This also refers to the advertising messages broadcast mainly by private television channels. The EU legislation Greece adopted is not fully obeyed by the media, or the advertising industry either. The paper outlines the history and importance of the Greek mass media, the advertising policy of some television stations and also refers to large format advertising. It should be pointed out that the facts and conclusions presented by the author with reference to advertising messages and television come from the research he conducted in Greece from 2008 through 2010.

18 Art. 77, ibidem, s. 86. 
